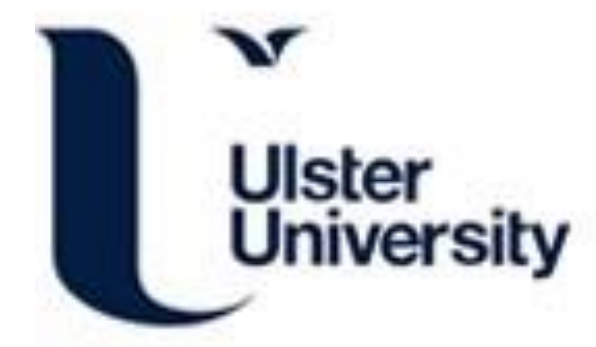

\title{
Sandy beaches can survive sea-level rise
}

Cooper, A., Masselink, G., Coco, G., Short, A., Castelle, B., Rogers, K., Anthony, E., Green, A., Kelley, J., Pilkey, O., \& Jackson, DWT. (2020). Sandy beaches can survive sea-level rise. Nature Climate Change, 10(11), 993-995. https://doi.org/10.1038/s41558-020-00934-2

Link to publication record in Ulster University Research Portal

\section{Published in:}

Nature Climate Change

\section{Publication Status:}

Published online: $27 / 10 / 2020$

DOI:

10.1038/s41558-020-00934-2

\section{Document Version}

Author Accepted version

\section{General rights}

Copyright for the publications made accessible via Ulster University's Research Portal is retained by the author(s) and / or other copyright owners and it is a condition of accessing these publications that users recognise and abide by the legal requirements associated with these rights.

\section{Take down policy}

The Research Portal is Ulster University's institutional repository that provides access to Ulster's research outputs. Every effort has been made to ensure that content in the Research Portal does not infringe any person's rights, or applicable UK laws. If you discover content in the Research Portal that you believe breaches copyright or violates any law, please contact pure-support@ulster.ac.uk. 


\section{Sandy beaches can survive sea-level rise}

2 J.A.G. Cooper ${ }^{1,2}$, G. Masselink ${ }^{3}$, G. Coco ${ }^{4}$, A.D. Short ${ }^{5}$, B. Castelle ${ }^{6,7}$, K. Rogers ${ }^{8}$, E.

3 Anthony ${ }^{9,10}$, A.N. Green ${ }^{2}$, J.T. Kelley ${ }^{11}$, O.H. Pilkey ${ }^{12}$, D.W.T. Jackson ${ }^{1}$

4

5 Arising From: Vousdoukas et al. Nature Climate Change

6 https://doi.org/10.1038/s41558-020-0697-0

7

8 1. Geography and Environmental Science, Ulster University, Coleraine, BT52 1SA,

$9 \quad$ UK: email: jag.cooper@ulster.ac.uk

10 2. Geological Sciences, University of KwaZulu-Natal, Durban, South Africa

11 3. Coastal Processes Research Group, Plymouth University, Drake Circus, PL4 8AA

12 Plymouth, UK

13 4. School of Environment, Faculty of Science, University of Auckland, New Zealand.

14 5. School of Geosciences, University of Sydney, NSW 2006, Australia

15 6. UMR EPOC 5805, Univ. Bordeaux, 33615 Pessac, France

16 7. UMR EPOC 5805, CNRS, 33615 Pessac, France

17 8. School of Earth, Atmospheric and Life Sciences, University of Wollongong,

18 Northfields Ave, Wollongong, NSW, 2522, Australia

19 9. Aix Marseille University, CNRS, IRD, INRA, Coll France, CEREGE, Aix-en20 Provence, France

21 10. USR LEEISA, CNRS, Cayenne, French Guiana

22 11. School of Earth and Climate Sciences, University of Maine, Orono ME 04469235790 , USA

24 12. Nicholas School of the Environment, Duke University, Durham, NC, USA

26 Vousdoukas et al. ${ }^{1}$ assert that global sea-level rise (SLR), poses a threat to the 27 existence of sandy beaches. They use global data bases of sandy beaches, 
bathymetry and wave conditions to drive a simple model based on the 'Bruun Rule' to quantify shoreline retreat, to which they add a background ambient trend based on satellite data. When retreat is more than $100 \mathrm{~m}$ by 2100 , they declare those beaches near-extinct by the end of the century. We feel this is an incorrect and potentially damaging finding. Critical to the paper's conclusions is the fact that, provided accommodation space is available, beaches migrate landwards as sea level rises and shorelines retreat. Many contemporary beaches formed thousands of years ago and migrated landwards during postglacial SLR ${ }^{2}$. Globally, hundreds of beaches have been retreating at rapid rates for more than a century, but have not been extinguished ${ }^{3}$. In SW France, for example, the shoreline has receded $>100 \mathrm{~m}$ but still has wide and healthy beaches ${ }^{4}$. The underlying premise of Vousdoukas et al. ${ }^{1}$ originates in an inappropriate model, the 'Bruun Rule', in which SLR promotes offshore sediment transport. As stated in their Methods section: SLR-induced shoreline retreat "...depends on the amplitude of SLR and the transfer of sediment from the subaerial to the submerged part of the active beach profile". Offshore sediment transport might happen in cases of very steep topography, but in most cases sediment transport is onshore during SLR ${ }^{2,5}$.

Sandy beaches are highly variable in form and setting, and it is widely accepted that there is no single response to $S L R^{2,5}$. They may (i) migrate landwards due to onshore sediment transport via overwash without loss of beach width (e.g., barrier beaches on relatively gentle substrates), (ii) experience recession due to offshore sediment transport (e.g., beaches backed by non-erodible cliffs or sea walls), or (iii) be stranded on the seabed (overstepped) as intact sand bodies (this requires very rapid SLR, and/or particular combinations of morphology and sediment supply $)^{6}$. Beaches may even (iv) prograde under SLR when the sediment budget is overwhelmingly positive ${ }^{7}$. Where well-developed dune systems are present, sediment supply from the eroding dunes may significantly temper SLR-induced coastal retreat. Sandy shoreline response to SLR depends on many local environmental factors, including coastal morphology, sediment supply and transport (onshore, offshore, longshore), rate (not just amount) of SLR, and the ambient nearshore dynamics. The paper's methodology ${ }^{1}$ is based on a single model (the Bruun Rule) with the addition of a background shoreline trend. For settings characterised by very significant background shoreline changes (e.g., deltaic shorelines), inclusion of the ambient trend might encompass the 
61 local/regional factors, but elsewhere local factors (e.g., presence of dunes, sub-beach bedrock outcrop, shore protection structures) are likely to dominate the shoreline response.

64 The Bruun Rule's shortcomings have been well-documented ${ }^{8-12}$, and alternatives are 65 being sought by some researchers ${ }^{9-12}$. As applied in this paper, it requires a spaceand time-invariant cross-shore profile, ignores sediment supply, is strictly 2dimensional and considers only amount (not rate) of SLR. Crucially, it does not account for the topography, or the material nature of the basement over which the beach is migrating (Fig. 1). Its central mechanism (offshore transport of sand during SLR) is not a valid process on the majority of the world's beaches. Even in locations where this mode of shoreline retreat may operate, a beach is still predicted to remain, which appears to be overlooked in the paper by Vousdoukas et al.. Where it is not a valid description of shoreline behaviour it should not be applied. Past and erroneous applications of the Bruun Rule at regional and global scale do not provide justification for continuation of the practice.

Additional methodological shortcomings include use of an arbitrary 1:300 beach gradient cut-off to avoid excessive recession rates and an arbitrary constant ( $E$ factor) to moderate the predicted shoreline retreat. $E$ is randomly generated to range between 0.1 and 1.0, centred around a median of 0.75 . The constructed distribution of $E$ is not based on any evidence of its distribution.

81 The headline result of this paper - "the near extinction of almost half of the world's 82 sandy beaches" - requires an arbitrary and unjustified amount of shoreline retreat of $83100 \mathrm{~m}$. Where a beach is backed by a sea defence structure, it will be eroded, but if 84 accommodation space exists (as in most of the world's beaches), it will migrate. Coastal erosion is a complex process that requires rigorous consideration of local, regional and global factors, and reliable models. Collectively, the assumptions and shortcomings that characterise the approach in this paper ${ }^{1}$ inhibit the formulation of reliable and robust predictions of shoreline change due to SLR.

89 Some coasts for which application of the Bruun model is especially inappropriate are 90 highlighted by Vousdoukas et al. ${ }^{1}$. The Suriname coast, for example, is subject to the overarching influence of large mud banks migrating along the inner shoreface ${ }^{13}$. Moreover, there is no major beach-related tourism and only few artificial impediments 
93 to shoreline migration. Australia is singled out as the country potentially most affected 94 by sandy beach erosion, primarily because it has a very long coastline; however, in reality, Australia has a low risk of beach loss because the overwhelming majority of the coastline is undeveloped, allowing for unimpeded beach migration.

97 Planning for SLR is necessary, but the paper's mention of Dutch engineering as a

98 solution is inappropriate. The necessary expertise, economy, and nearshore sand supplies exist in few locations outside the Netherlands. Locking other nations into large-scale efforts to hold the shoreline would be economically and environmentally disastrous.

Sandy beach response to SLR is highly site-specific and temporally variable ${ }^{14}$. Vousdoukas et al.'s ${ }^{1}$ generalization of complex processes and extrapolations of data sets to large spatial (i.e., global) and long temporal (i.e., to 2100) scales are inappropriate. They do not present a global analysis; rather, it is a local analysis undertaken for the whole planet. The same model is applied everywhere using datasets (waves, beach slope) that provide local measurements but without detail on important local constraints ${ }^{14}$ on shoreline behaviour. Failure at the local level, where computations are performed, cascades into their integrated results. Incorrect model outputs may unnecessarily cause alarm, as has been the case with this paper, and could prompt inappropriate policy responses.

Instead of global applications of flawed concepts, new methods are needed for predicting impacts of SLR on the coast. This will require better datasets of coastal morphology (in the satellite-derived datasets used in this paper, for example, many "sandy beaches" are misidentified) and improved understanding of the mechanisms of shoreline response in given settings. As sea level rises, shoreline retreat must, and will, happen. Beaches, however, will survive. The biggest threat to the continued existence of beaches is coastal defence structures that limit their ability to migrate ${ }^{15}$.

\section{References}


121 1. Vousdoukas, M.I. et al. Sandy Beaches under threat of erosion. Nat. Clim. Change, 10, 260-263 (2020).

123 2. Carter, R.W.G. \& Woodroffe, C.D. Coastal Evolution. Cambridge University 124 Press (1994).

125 3. Bird, E.C.F. Coastline changes: a global review. Wiley, Chichester (1985)

4. Castelle, B. et al. Spatial and temporal patterns of shoreline change of a 280km high-energy disrupted sandy coast from 1950 to 2014: SW France. Est. Coast. Shelf Sci., 200, 212-223 (2018).

5. Woodroffe, C.D. Coasts: form, process and evolution. Cambridge University Press (2002).

6. Green, A.N. et al. Geomorphic and stratigraphic signals of postglacial meltwater pulses on continental shelves. Geology, 42, 151-154 (2014).

7. Brooke, B.P. et al. Relative sea-level records preserved in Holocene beachridge strandplains-An example from tropical northeastern Australia. Mar. Geol., 411, 107-118 (2019)

8. Cooper, J.A.G. \& Pilkey, O.H. Sea-level rise and shoreline retreat: time to abandon the Bruun Rule. Glob. Planet. Change, 43, 157-171 (2004).

9. Rosati, J.D. et al. The modified Bruun Rule extended for landward transport. Marine Geology, 340, 71-81 (2013).

10.Dean, R.G. \& Houston, J.R. Determining shoreline response to sea level rise. Coastal Engineering, 114, 1-8 (2016).

11.Davidson-Arnott, R.G. Conceptual model of the effects of sea level rise on sandy coasts. Journal of Coastal Research, 1166-1172 (2005).

12. Wolinsky, M.A., \& Murray A.B. A unifying framework for shoreline migration: 2. Application to wave-dominated coasts. J. Geophys. Res.,114, F01009, doi:10.1029/2007JF000856 (2009).

13. Anthony, E. et al. Chenier morphodynamics and degradation on the Amazoninfluenced coast of Suriname, South America: implications for beach ecosystem services. Frontiers in Earth Science, 7, 35 (2019).

14. Cooper, J.A.G. et al. Geological constraints on mesoscale coastal barrier behaviour. Glob. Planet. Change, 168, 15-34 (2018). 


\section{Figure Caption}

156 Figure 1. The geomorphology and material landward of a sand beach is an important

157 determinant of its behavior under sea level rise. Sea level rise can tap into onshore 158 sand supplies, thus ensuring continued healthy beaches. The arid Namibian coast (A) 159 with its bare sand and the subtropical KwaZulu-Natal coast (B) with vegetated sand 160 dunes are dramatic examples. The paraglacial coast of Northern Ireland (C) also 161 contains beaches backed by erodible, sediment-supplying glacigenic sediments that 162 will sustain beaches as sea levels rise. A cliff or seawall-backed beach such as at 163 Oostend, Belgium (D), however, is cut off from adjacent sand-supplying dunes. As 164 sea-level rises it will suffer coastal squeeze and disappear or be artificially replenished.

165 (Credits: Photograph A. Andrew Green; Photographs B,C,D. Andrew Cooper.) 